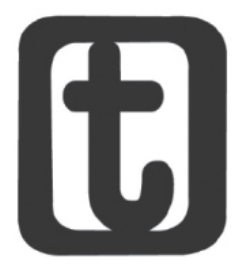

\title{
CAMPANHA DA VIA CAMPESINA SOBRE OS AGROTÓXICOS
}

Via campesina's agro-toxins campaign

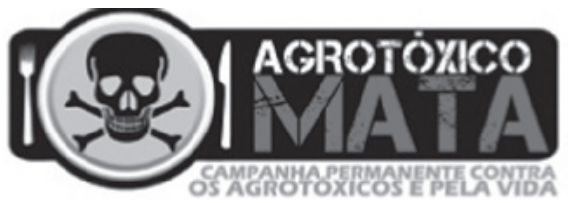

Campanha Permanente

Contra os Agrotóxicos e Pela Vida

O Brasil é o primeiro colocado no ranking mundial do consumo de agrotóxicos. Mais de um milhão de toneladas de venenos foram joga-

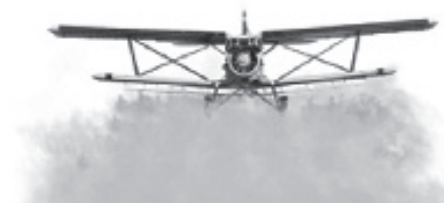
dos nas lavouras em 2010, de acordo com dados do Sindicato Nacional da Indústria de Produtos para a Defesa Agrícola.

Com a aplicação exagerada de produtos químicos nas lavouras do país, o uso de agrotóxicos está deixando de ser uma questão relacionada especificamente à produção agrícola e se transforma em um problema de saúde pública e preservação da natureza.

O consumo de agrotóxicos cresce de forma correspondente ao avanço do agronegócio, modelo de produção que concentra a terra e utiliza quantidades crescentes de venenos para garantir a produção em escala industrial.

Desta forma, o uso excessivo dos agrotóxicos está diretamente relacionado à atual política agrícola do país, que foi adotada a partir da década de 1960. Com a chamada Revolução Verde, que representou uma mudança tecnológica e química no modo de produção agrícola, o campo passou por uma "modernização" que impulsionou o aumento da produção, mas de forma extremamente dependente do uso dos pacotes agroquímicos [adubos, sementes melhoradas e venenos]. 
Segundo a Associação Brasileira da Indústria Química (Abiquim), na última safra foram vendidos mais de 7 bilhões de dólares em agrotóxicos. Todo este mercado se concentra nas mãos de apenas seis grandes empresas transnacionais, que controlam mais de $80 \%$ do mercado dos venenos. São elas: Monsanto; Syngenta; Bayer; Dupont; DowAgrosciens e Basf.

Nesse quadro, os agrotóxicos já ocupam o quarto lugar no ranking de intoxicações. Ficam atrás apenas dos medicamentos, acidentes com animais peçonhentos e produtos de limpeza. Essas fórmulas podem causar esterilidade masculina, formação de cataratas, evidências de mutagenicidade, reações alérgicas, distúrbios neurológicos, respiratórios, cardíacos, pulmonares, no sistema imunológico e no sistema endócrino, ou seja, na produção de hormônios, desenvolvimento de câncer, dentre outros agravos à saúde.

\section{O QUE É A CAMPANHA}

Diante dessa triste realidade mais de 30 entidades da sociedade civil brasileira, movimentos sociais, entidades ambientalistas, estudantes, organizações ligadas a área da saúde e grupos de pesquisadores lançaram a Campanha Permanente Contra os Agrotóxicos e Pela Vida. A Campanha pretende abrir um debate com a população sobre a falta de fiscalização no uso, consumo e venda de agrotóxicos, ademais disso sobre a contaminação dos solos e das águas bem como denunciar os impactos dos venenos na saúde dos trabalhadores, das comunidades rurais e dos consumidores nas cidades.

Para além de denunciar as mazelas causadas pelas empresas e pelo uso de agrotóxicos, é preciso construir formas de restringir o uso de venenos e de impedir sua expansão, propondo projetos de lei, portarias e iniciativas legais e jurídicas.

Doenças causadas por agrotíxicos

Saha alyunas das dcenças agudes e crtricas

causaths pels unenes nes trablhaderes, ass

famiks, populațīes qua meram parto das

foxencbs a masumidors am garal.

- Ma formacio fetal

- Dur de catega

- Dzariéa

- Virrilrs

- Desmains

- Nlisisezs

- Problanas de rim

- Daençs de pala

- Lritzeslo collar

eaviliva

- Depnessit

- Lesajo naurdógia

- Cànser

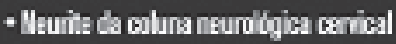

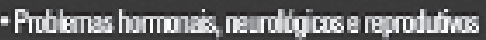

Outro campo de atuação da campanha é o anuncio da possibilidade de construção de um outro modelo agrícola, baseado na agricultura camponesa e agroecológica. Temos estudos que comprovam que essa forma de produzir é viável, produz em quantidade e em 
qualidade suficientes para abastecer o campo e a cidade. Então propomos avançar na construção destas experiências que são a única saída para esse modelo imposto que concentra riquezas, expulsa a população do campo e produz pobreza e envenenamento. Produzir alimentos saudáveis com base em princípios agroecológicos, em pequenas propriedades, com respeito à natureza e aos trabalhadores é a única forma de acabar com a fome e de garantir qualidade de vida para as atuais e futuras gerações.

\section{OBJETIVOS}

Podemos elencar como principais objetivos da campanha:

1-Construir um processo de conscientização na sociedade sobre a ameaça que representam os agrotóxicos, denunciando assim todos os seus efeitos degradantes à saúde, ao meio ambiente, etc;

2-Denunciar e responsabilizar as empresas que produzem e comercializam agrotóxicos;

3-Pautar na sociedade a necessidade de mudança do atual modelo agrícola que produz comida envenenada;

4-Fazer da campanha um espaço de construção de unidade entre ambientalistas, camponeses, trabalhadores urbanos, estudantes, consumidores e todos aqueles que prezam pela produção de um alimento saudável que respeite ao meio ambiente;

5-Explicitar a necessidade e o potencial que o Brasil tem de produzir alimentos diversificados e saudáveis para todos, em pleno convívio com o meio ambiente com base em princípios agroecológicos.

\section{CONTATOS}

Para atingir nossos objetivos é preciso que a Campanha se enraíze através da construção de comitês locais, para que todas as iniciativas possam ser absorvidas pelo conjunto da sociedade. As denúncias precisam chegar às escolas, igrejas, rádios locais, jornais do bairro, para que o povo possa discutir que tipo de comida quer se alimentar. Venha participar conosco na luta contra os agrotóxicos e pela vida!

Secretaria Operativa Nacional

fones: (11) 3392-2660/ (11) 7181-9737

e-mail: contraosagrotoxicos@gmail.com

skype: contraosagrotoxicos 